\title{
Exploration and Practice of Ideological and Political Education in Mechanical Design Course
}

\author{
Wangyuan Zong \\ Huazhong agricultural university \\ Hubei province, China \\ zwy@mail.hzau.edu.cn \\ Hong Chen \\ Huazhong agricultural university \\ Hubei province, China \\ chenhong@mail.hzau.edu.cn
}

\author{
Hong Zhai * \\ Huazhong agricultural university \\ Hubei province, China \\ 290009464@qq.com \\ Haibing Pan \\ Huazhong agricultural university \\ Hubei province, China \\ 158198690@qq.com
}

\begin{abstract}
In order to make full use of the main channel of classroom teaching and enhance the affinity and pertinence of ideological and political education, each course should keep a section of the canal and plant a good responsibility field. Form a synergistic effect; shoulder the important mission of instructors and guides for students' healthy growth. On the basis of in-depth understanding and thinking, the work carried out the exploration and practice of Ideological and political education in the mechanical design class in the autumn semester of 2018. We have made a series of explorations and practices through digging into many ideological and political elements in the classroom, and achieved certain results, and promoted them in a certain range.
\end{abstract}

Keywords-Ideological and Political Education; Mechanical Design; National Feelings; Teaching Methods

\section{Proposal FOR COURSE IDEOLOGICAL AND POLITICAL EDUCATION}

On December 7, 2016, at the National Conference on ideological and Political Work in Colleges and Universities, General Secretary Xi Jinping stressed that the development direction of higher education in China should be closely linked with the realistic goal and future direction of China's development, serving the people, serving the governance of the communist party of China, serving the consolidation and development of the socialist system with Chinese characteristics, serving the reform and opening up and socialist modernization. The ideological and political work in Colleges and universities is related to the fundamental question of what kind of people they train, how to train people and who to train people for ${ }^{[1]}$. We should persist in taking moral education as the central link, run ideological and political work through the whole process of education and teaching, and realize the whole process and all-round education. To do a good job of ideological and political work in colleges and universities, we should change according to the situation, advance according to the time, be new according to the situation. We should follow the law of ideological and political work, the law of teaching

National new engineering comprehensive reform project (based on the exploration and practice of the cultivation mode of agricultural engineering talents in agricultural and forestry colleges and universities with multidisciplinary integration), project number: 2018117. and educating people, the law of students' growth, and constantly improve our working ability and level. Therefore, from ideological and political education to professional ideological and political education is an important measure to integrate ideological and political education into classroom education in response to General Secretary Xi's proposal.

\section{Mechanical Design Course IdeOlogical Politics IS THE ERA OF HIGHER EDUCATION NEEDS}

Teachers are the engineers of the human soul, shouldering the sacred mission, university teachers should insist that educators receive an education first, strive to become a disseminator of advanced ideology and culture and a staunch supporter of the Party in power, better shoulder the responsibility of the instructor and guide for students' healthy growth. We should make good use of classroom teaching as the main channel to enhance the affinity and pertinence of ideological and political education, so as to meet the growth and development needs and expectations of students. All other courses should follow a section of channel and cultivate a good responsibility field, so that all courses and ideological and political theory courses will be in the same direction and form a synergistic effect [2]. Xi Jinping emphasized at the National Education Congress on September 10, 2018 that under the strong leadership of the Party, we should train socialist builders and successors with all-round development of morality, intelligence, physical fitness, beauty and labor, accelerate the modernization of education, build a strong educational country and run a satisfactory education for the people [3].

The machinery industry is the pillar industry of the national economy and an important symbol of the development level of social productive forces. In China's colleges and universities, science and engineering colleges account for more than half of the total number of colleges and universities. Almost all of them have mechanical specialties [4], among which mechanical design is a basic course discussing the theory and methods of basic mechanical design. It plays the role of bridge and link from basic courses to specialized courses. It is a core compulsory course for mechanical majors, affecting students 
for a long time and involving a wide range of students. Reforming the original syllabus and teaching mode of mechanical design course, realizing the organic connection between ideological and political education and professional courses, based on the core principles and requirements of ideological and political education, organic combination of course teaching content and teaching activity design, excavating the elements of ideological and political education, is the practical need and important channel to implement $\mathrm{Xi}$ Jinping's thought on education of socialism with Chinese characteristics for a new era and cultivate China's mechanical engineering technical talents for a new era.

\section{THE PRACTICE OF IDEOLOGICAL AND POLITICAL EdUCATION IN THE TEACHING PROCESS Of MECHANICAL DESIGN COURSE}

To carry out ideological and political education in the teaching of specialized courses, we should not only solve the problem of docking ideological and political education with curriculum teaching, but also solve the problem of teaching methods of integrating ideological and political education into curriculum teaching. In practice, in order to achieve the natural integration of professional content, we should moisten things silently. In the teaching practice, the course group combines the following relevant teaching links and knowledge points and embeds the content of ideological and political education, so as to realize the seamless docking of ideological and political education in professional courses.

The author puts forward that the pilot project of ideological and political education for mechanical design courses in our school has been approved. In the autumn semester of 2018, all the teachers in the course group of mechanical design brainstormed, thought actively, and combined with the professional courses to dig deeply into many elements of ideological and political courses, made a series of bold explorations and practices, and introduced them in a certain range, which played a certain exemplary role. Some specific courses are combined with ideological and political education as follows:

A. From the beginning of the professional course to why to study, we should integrate into the education of the

feelings of home and country, sense of historical mission and sense of social responsibility

It coincides with the theme of the school's revival in 2018. When the first professional class begins, the theme is introduced appropriately. It tells the story of Zhou Enlai's reading for the rise of China. It extends to the fact that college students are the elite group of society and should shoulder the due responsibilities of the times. When describing the position and role of machinery industry in the national economy, the course illustrates the role of machinery industry and the achievements of the development of Engineering Science and technology in China by taking into account a series of Engineering examples, such as high-speed rail, large aircraft, Jiaolong Deep-sea Detector and bridge construction mentioned in documentaries such as heavy weapons and super-engineering of big powers, and draws forth four self-confidence, Then extends to four consciousness and four service.

\section{B. Understanding and understanding of the materialist dialectics of the Communist Party of China and the mass line through forging parts and materials}

When describing the design method of mechanical design drawing lessons from and innovating, it leads to the topics of left-leaning and right-leaning, reform and opening-up, adherence to the four basic principles, and socialist market economy. Enhance students' understanding of the socialist road with Chinese characteristics in the new era, and practical and realistic ways of thinking. When describing the material selection of mechanical parts, one of the forming methods of steel blanks is forged steel, which leads to the formation of good steel through thousands of hammers, guides students to correctly deal with difficulties in life, regards difficulties as opportunities for their own growth and improvement, and puts forward the correct treatment of criticism from teachers and parents, and correctly treats criticism and self-criticism. It further leads to the three excellent styles of work of the Communists, integrating theory with practice, closely linking the masses, criticism and self-criticism.

\section{From the timeliness and assembly principle of parts to the cultivation of collective concept and overall situation consciousness}

The aging treatment methods of mechanical parts materials include vibration aging and natural aging, which can guide students to talk with their teachers when they have unsolvable mental knots (vibration aging). If they can't solve difficulties or contradictions, they may as well put it aside first (natural aging). The anti-loosening principle of series steel wire in bolt group extends to the limited ability of each person. Everyone in the group must play a role. Only by coordinating and cooperating with each other can the members of the group successfully complete the project task. When describing the general process of mechanical design, ask questions about the sequence of drawing assembly drawings and parts drawings, and lead to the idea of doing things with overall awareness and overall situation. The bolt group connection needs moderate pre-tightening, which can enhance the tightness and reliability of the connection. The students' class collective must be restrained by discipline, cooperate with each other and supervise each other so as to have a good style of study and combat effectiveness.

\section{Discuss how to enhance the self-discipline consciousness of the individual from the thread self-locking}

Thread connection has self-locking property, but self-locking is only reliable under certain parts. When the external load changes greatly, the connection may fail, and some loosening prevention measures are needed to ensure the reliability of the connection. The same is true of students' self-discipline and learning self-consciousness. In the absence of external influence and external interference, everyone does well. When external influence is greater or reaches a certain degree, students' self-discipline and concentration will be affected. If there is a little wind and grass outside the window, everyone will not pay attention to it. When there is a strong wind outside, you may take a look. Closing doors and windows and reminding students are all measures to reduce or isolate the impact. At the same time, I hope that through their own efforts, 
students can improve their concentration in class and maintain their determination in life. The fatigue damage of parts is caused by the gradual growth of small initial cracks. Therefore, it is proposed that students should pay attention to the prevention of gradual growth, overcome some minor bad habits of individuals, and enhance self-discipline consciousness and self-control ability.

\section{E. Integrating with the introduction of "gear character", we} should strengthen the understanding and think of College Students' personality integrity

Gear is a very important part in mechanical design, which extends to students who have high comprehensive quality and play an important role. The characteristics of gear material are summarized as "external hardness and internal toughness". That is to say, the hardness of the gear surface should be high to prevent pitting and gluing damage, and the overall toughness of the gear interior should be good to prevent the gear teeth from breaking under overload. Guiding students to be human should also be "hard outside and tough inside". "External hardness" means being too hard in style, consciously cultivating good habits and habits, and cultivating good personal image and personality. "Inner resilience" means to have tough character and strong psychology. At the same time, using historical figures Cao Cao and Zhou Yu as a contrast, we can educate students not to be discouraged, not to give up and not to "break" when they encounter setbacks.

\section{Some Thoughts on Course IDEOLOGY AND Politics}

\section{A. Deeply implement the concept of ideological and political} education and exert a synergistic effect

Give full play to the school education should have 360 degrees moral education "melting pot" joint force. Constructing the ideological and political theory course, comprehensive literacy course and professional course trinity of the ideological and political course system in Colleges and universities, giving full play to the role of "leading dance" in ideological and political courses, and realizing the effect of "dancing together" in all courses.

\section{B. The ideological and political education of the curriculum should be salty and light and moisten things silently}

Course ideological and political education must be a silent process of moistening things. The key lies in how to persist in it for a long time, influence it imperceptibly, and promote it effectively. Ideological and political education for professional courses, like salt for food, less no taste, more is not good.

\section{The ideological and political education of the curriculum embodies the mutual improvement of teaching and learning}

Course ideological and political education is also to enhance the professional curriculum itself. The construction process of curriculum ideological and political education is also for teachers' self-education.

\section{Organically integrate professional education objectives with ideological and political education teaching objectives}

The teaching goal of ideological and political education is to cultivate students' patriotic and patriotic feelings of the Party and the country, respectful and professional personality, and to form materialistic and dialectical thinking methods while teaching professional courses.

\section{CONCLUSION}

Since the pilot project of course ideology and politics was carried out in the students' professional class, the course teachers of this professional course group actively made suggestions and put their heads together to design the class skillfully, dig deep into the elements of course ideology and politics, and moisten things silently into the class, so as to blend into the students' hearts. With the help of the course ideological and political process, students' professional quality, learning enthusiasm, patriotic enthusiasm, and social responsibility are fully aroused. Meanwhile, teaching and learning can benefit from each other, and it can be promoted and play a demonstration role in other professional courses.

\section{REFERENCE}

[1] Xi Jinping stressed at the National Conference on Ideological and Political Work in Colleges and Universities that the ideological and political work should run through the whole process of education and teaching to create a new situation for the development of higher education in China [N]. People's Daily, 2016-12-09 (1).

[2] Xi Jinping, General Secretary of the CPC Central Committee, President of the State and Chairman of the Central Military Commission, attended the National Conference on Ideological and Political Work in Colleges and Universities from 7 to 8 December 2016 and delivered important speeches.

[3] Xi Jinping. Adhere to the road of socialist education development with Chinese characteristics, train socialist builders and successors with all-round development of morality, intelligence, physical fitness, beauty and labor [EB/OL]. (2018-09-10) [2019-04-20]. http: www.xinhuanet.com/politics/lead-ers/2018-09/10/c_11204400.htm.

[4] Present Situation of Advanced Technologies in Machinery Industry of Our Country "Hot Processing Technology" 2005.7 